\title{
Flux correction for closed-path laser spectrometers without internal water vapor measurements
}

\author{
R. V. Hiller ${ }^{1}$, C. Zellweger ${ }^{2}$, A. Knohl ${ }^{3}$, and W. Eugster ${ }^{1}$ \\ ${ }^{1}$ Institute of Agricultural Sciences, ETH Zurich, Zürich, Switzerland \\ ${ }^{2}$ Empa, Materials Science \& Technology, Dübendorf, Switzerland \\ ${ }^{3}$ Institute of Bioclimatology, Georg-August University of Göttingen, Göttingen, Germany
}

Received: 13 December 2011 - Accepted: 14 December 2011 - Published: 10 January 2012

Correspondence to: R. V. Hiller (hillerr@ethz.ch)

Published by Copernicus Publications on behalf of the European Geosciences Union.

\begin{abstract}
Recently, instruments became available on the market that provide the possibility to perform eddy covariance flux measurements of $\mathrm{CH}_{4}$ and many other trace gases, including the traditional $\mathrm{CO}_{2}$ and $\mathrm{H}_{2} \mathrm{O}$. Most of these instruments employ laser spec5 troscopy, where a cross-sensitivity to $\mathrm{H}_{2} \mathrm{O}$ is frequently observed leading to an increased dilution effect. Additionally, sorption processes at the intake tube walls modify and delay the observed $\mathrm{H}_{2} \mathrm{O}$ signal in closed-path systems more strongly than the signal of the sampled trace gas. Thereby, a phase shift between the trace gas and $\mathrm{H}_{2} \mathrm{O}$ fluctuations is introduced that dampens the $\mathrm{H}_{2} \mathrm{O}$ flux observed in the sampling cell. For

10 instruments that do not provide direct $\mathrm{H}_{2} \mathrm{O}$ measurement in the sampling cell, transfer functions from externally measured $\mathrm{H}_{2} \mathrm{O}$ fluxes are needed to estimate the effect of $\mathrm{H}_{2} \mathrm{O}$ on trace gas flux measurements. The effects of cross-sensitivity and the damping are shown for an eddy covariance setup with the Fast Greenhouse Gas Analyzer (FGGA, Los Gatos Research Inc.) that measures $\mathrm{CO}_{2}, \mathrm{CH}_{4}$, and $\mathrm{H}_{2} \mathrm{O}$ fluxes. This 15 instrument is technically identical with the Fast Methane Analyzer (FMA, Los Gatos Research Inc.) that does not measure $\mathrm{H}_{2} \mathrm{O}$ concentrations. Hence, we used measurements from a FGGA to derive a modified correction for the FMA accounting for dilution as well as phase shift effects in our instrumental setup. With our specific setup for eddy covariance flux measurements, the cross-sensitivity counteracts the damping effects, which compensate each other. Hence, the new correction only deviates very slightly from the traditional Webb, Pearman, and Leuning density correction, which is calculated from separate measurements of the atmospheric water vapor flux.
\end{abstract}

\section{Introduction}

The eddy covariance technique $(E C)$ is the established method to directly measure the exchange of trace gases, such as $\mathrm{CO}_{2}$ and $\mathrm{H}_{2} \mathrm{O}$, between the land surface and the atmosphere (Baldocchi, 2003). Recently, new instruments became available that are 
suitable to measure fluxes of additional trace gases, such as $\mathrm{CH}_{4}$ or $\mathrm{N}_{2} \mathrm{O}$ (e.g. Eugster and Plüss, 2010; Smeets et al., 2009; Neftel et al., 2010; Hendriks et al., 2008; Kroon et al., 2007; Eugster et al., 2007). However, by careful evaluation of the suitability of the instrument for the EC method, it becomes clear that some adaptations of the 5 standard processing techniques, e.g. accounting for cross-sensitivity effects with $\mathrm{H}_{2} \mathrm{O}$, are needed (McDermitt et al., 2010).

Most new instruments apply laser spectroscopy to measure trace gases and two general types of instruments can be distinguished: (1) closed-path instruments pull air through a sampling cell where the air is measured, and (2) open-path instruments mea-

10 sure the composition of the air directly in the atmosphere. Both types of instruments measure the decay of a laser beam over a known distance (Baer et al., 2002; McDermitt et al., 2010). In closed-path instruments, the beam is reflected by mirrors to achieve a path length of several kilometers (Baer et al., 2002; Crosson, 2008). The definition of the spectral line assumes that the gas matrix does not change. Atmospheric water 15 content can however vary considerably and thus broaden the spectral line. Hence, the instrument or the post-processing of the data have to account for this effect (Rella, 2010). This phenomenon was described for a Quantum Cascade Laser (QCL, Aerodyne Research Inc.) by Neftel et al. (2010), and for a Fast Methane Analyzer (FMA, Los Gatos Research Inc.) by Tuzson et al. (2010). Picarro Inc. discussed the issue

20 for their laser spectroscopy-based instrument G1301 in a white paper (Rella, 2010). The same artifact also influences open-path instruments such as the LI-7700 (Li-Cor) where a combined correction accounts for the dilution as well as for the additional $\mathrm{H}_{2} \mathrm{O}$ interference on the measured $\mathrm{CH}_{4}$ flux (McDermitt et al., 2010). With closed-path instruments, one solution would be to dry the air prior to sampling. However, this tends

25 to have a negative impact on the frequency response and high-frequency performance of the sensor (Griffis et al., 2008). Alternatively, a correction procedure could solve the cross-sensitivity issue in a more elegant way as will be discussed in this paper.

Since the FMA does not measure $\mathrm{H}_{2} \mathrm{O}$, the correction of the density effect caused by water vapor molecules is essential to improve the accuracy of the flux measurements.

Therefore, the $\mathrm{H}_{2} \mathrm{O}$ flux measured by a separate system is typically used to apply this correction. The traditional density flux correction by Webb et al. (1980) employs the water vapor flux measured in the same sampling cell as the other gas of interest. The water vapor signal however gets more strongly dampened from the inlet to the sampling 5 cell (Ibrom et al., 2007a) than a less polar gas such as $\mathrm{CH}_{4}$. Thus, substituting the water vapor flux in the original correction term with the water vapor flux measured separately with a second instrument and at some distance from the first instrument might overcorrect the density effect. To find out whether this is a small (negligible) or large and important effect was the goal of this study.

10 We used a Fast Greenhouse Gas Analyzer (FGGA, Los Gatos Research Inc.) to asses the phase shift and damping of the $\mathrm{H}_{2} \mathrm{O}$ signal with respect to the $\mathrm{CH}_{4}$ signal and in relation to an externally measured $\mathrm{H}_{2} \mathrm{O}$ flux. Based on these findings, two transfer functions will be suggested to (1) correct the $\mathrm{H}_{2} \mathrm{O}$ flux measured by the FGGA to represent atmospheric conditions; and (2) its inverse function that allows to translate

15 an externally measured $\mathrm{H}_{2} \mathrm{O}$ flux to the conditions in the sampling cell which then can be used to correct the $\mathrm{CH}_{4}$ flux for the density fluctuations. This correction procedure can be used to correct $\mathrm{CH}_{4}$ flux measurements performed with a FMA which does not provide internal $\mathrm{H}_{2} \mathrm{O}$ measurements.

\section{Background}

20 This study closely follows the concept of the density flux correction accounting for density effects due to heat and water vapor fluctuations that was introduced by Webb et al. (1980). We will shortly introduce the concept of the theory and highlight the importance in relation to this study. The original concept will be referred to as WPL correction thereafter.

25 For water vapor, the original correction for open-path analyzers reads (WPL Eq. 25):

$$
E=(1+\mu \sigma)\left\{E_{\mathrm{raw}}+\left(\overline{\rho_{\mathrm{v}}} / \bar{T}\right) \overline{W^{\prime} T^{\prime}}\right\}
$$


with $E\left[\mathrm{~kg} \mathrm{~m}^{-2} \mathrm{~s}^{-1}\right]$ the corrected water vapor flux, $\mu=\frac{m_{\mathrm{a}}}{m_{\mathrm{v}}} \approx 28.97 / 18[-]$ the ratio of molecular masses of dry air and water vapor, $\sigma=\frac{\rho_{v}}{\rho_{\mathrm{a}}}[-]$ the ratio of the vapor density and the density of dry air, $E_{\text {raw }}\left[\mathrm{kg} \mathrm{m}^{-2} \mathrm{~s}^{-1}\right]$ the measured water vapor flux, $\overline{\rho_{\mathrm{v}}}\left[\mathrm{kg} \mathrm{m}^{-3}\right]$ the density of dry air, $T[\mathrm{~K}]$ the air temperature, and $\overline{w^{\prime} T^{\prime}}\left[\mathrm{Km} \mathrm{s}^{-1}\right]$ the sensible heat 5 flux in kinematic units.

For trace gas fluxes, buoyancy effects from water vapor additionally influence the measured flux. Thus, Webb et al. (1980) introduced the following correction (WPL Eq. 24):

$F=F_{\text {raw }}+\Delta F=F_{\text {raw }}+\underbrace{\mu\left(\overline{\rho_{\mathrm{c}}} / \overline{\rho_{\mathrm{a}}}\right) E}_{\text {water vapor }}+\underbrace{(1+\mu \sigma)\left(\overline{\rho_{\mathrm{c}}} / \bar{T}\right) \overline{w^{\prime} T^{\prime}}}_{\text {heat }}$,

10 where $F\left[\mathrm{~kg} \mathrm{~m}^{-2} \mathrm{~s}^{-1}\right]$ is the corrected trace gas flux and $F_{\text {raw }}$ the measured one. $\overline{\rho_{\mathrm{c}}}$ $\left[\mathrm{kg} \mathrm{m}^{-3}\right]$ denotes the density of the particular trace gas under consideration. The curly brackets summarize the correction terms for density fluctuations caused by the buoyancy effect of water vapor and by sensible heat. Taken together, they constitute $\Delta F$, the WPL correction term.

15 The sensitivity of the WPL correction itself largely depends on the ratio between the concentration of the particular trace gas under consideration and the corresponding flux. Largest WPL corrections are expected for small fluxes at comparably high background concentrations (Ibrom et al., 2007b). If $\overline{\rho_{\mathrm{c}}}$ is factored out in Eq. (2), it yields:

$$
F=F_{\text {raw }}+\overline{\rho_{\mathrm{c}}}\{\underbrace{\left(\mu / \overline{\rho_{\mathrm{a}}}\right) E}_{\text {water vapor }}+\underbrace{[(1+\mu \sigma) / \bar{T}] \overline{w^{\prime} T^{\prime}}}_{\text {heat }}\} .
$$

20 The term in the curly bracket to the right of $\overline{\rho_{\mathrm{c}}}$ is only influenced by the measurements of the environment and does not depend on the density of the trace gas nor

the trace gas flux. Therefore, the WPL correction $(\Delta F)$, the difference between the measured and the corrected flux, depends on the density of the trace gas multiplied by a term related to the environment conditions where the measurements was performed. This term includes the water content of the air, the water vapor flux, air tem5 perature, and the sensible heat flux. The relative magnitude of the WPL correction compared to the measured flux can be assessed by the ratio $\Delta F / F_{\text {raw. }}$. This is equal to $\left(\overline{\rho_{\mathrm{c}}} \times\right.$ environment $) / F_{\text {raw }}$ and hence the relative WPL correction is highest for high background concentrations $\left(\overline{\rho_{\mathrm{c}}}\right)$ combined with small fluxes $F_{\text {raw }}$. Detto et al. (2011) presented in their Fig. 6 the influence of the latent heat flux on $\mathrm{CH}_{4}$ flux for a closed10 path instrument, where the heat relatet component can be neglected based on the evindence that temperature fluctuations are almost completely removed in the closedpath instruments. However, since the WPL correction is an additive term and not a scaling factor, one should be careful with expressing the WPL correction as a percentage of the measured flux. This becomes most obvious at small fluxes, where the WPL 15 correction may lead to a sign change of the flux.

For closed-path instruments, the environment relevant for the WPL correction relates to the environment in the sampling cell, not to the ambient environment where the intake of the gas inlet was placed. Therefore, the water vapor and sensible heat flux in the cell define the magnitude of the WPL correction. In case of the sensible heat flux, 20 the tubing from the inlet to the measurement cell and the waste heat of the instrument cancel the natural short time temperature fluctuations. Hence, $\overline{w^{\prime} T^{\prime}}$ gets very small and the density effects due to heat transfer is negligible (Leuning and Judd, 1996). The correction term reduces to density effects due to water vapor. This term depends on various factors. If the air is dried prior to measurement or if concentrations are mea25 sured in units of dry mole fractions, this correction can be dismissed too. Otherwise, the term applies, but the instrumental setup may influence the measured $\mathrm{H}_{2} \mathrm{O}$ flux and consequently also the magnitude of the correction to be applied. Damping of the $\mathrm{H}_{2} \mathrm{O}$ signal reduces the $\mathrm{H}_{2} \mathrm{O}$ flux in a closed-path analyzer and thus the WPL correction would be overestimated by using $\mathrm{H}_{2} \mathrm{O}$ flux estimates taken from a second instrument 
(Ibrom et al., 2007b). The investigation of such effects is important to obtain the highest accuracy of trace gas flux measurements (Smeets et al., 2009). Signal damping due to amplitude effects (Massman and Clement, 2005) as well as phase shifts (Ibrom et al., 2007b) should be attributed.

5 The attenuation of the water vapor flux measured by a closed-path instrument depends on the relative humidity (Ibrom et al., 2007a; Mammarella et al., 2009). This however does not apply to $\mathrm{CO}_{2}$ and $\mathrm{CH}_{4}$ fluxes, since the molecules are not as sticky as $\mathrm{H}_{2} \mathrm{O}$ and hence do not strongly interact with the intake hose's inner wall. Thus, the transportation of the air through the instrument leads to a decoupling of the $\mathrm{CO}_{2}$

10 or $\mathrm{CH}_{4}$ and $\mathrm{H}_{2} \mathrm{O}$ signal (Ibrom et al., 2007b). This decoupling consequently results in a reduction of the water vapor flux at the time lag that was determined for the $\mathrm{CO}_{2}$ flux. Therefore, the WPL correction needs to be adjusted in a way that the $\mathrm{H}_{2} \mathrm{O}$ flux in the cell is approximated, as for example shown by lbrom et al. (2007b), Smeets et al. (2009), and Massman (2005).

\section{Methods}

\subsection{Instruments}

The Fast Methane Analyzer (FMA) and the Fast Greenhouse Gas Analyzer (FGGA, both Los Gatos Research Inc., Mountain View, CA, USA) are capable of measuring $\mathrm{CH}_{4}$ mole fractions. Both instruments operate at high measurement frequencies up 20 to $20 \mathrm{~Hz}$ as required for eddy covariance measurements. The construction of the two instruments is identical except for a second laser in the FGGA that measures $\mathrm{CO}_{2}$. $\mathrm{H}_{2} \mathrm{O}$ is also only measured by the FGGA, but retrieved from the same laser absorption spectrum as $\mathrm{CH}_{4}$. With the help of measurements with the FGGA, the influence of $\mathrm{H}_{2} \mathrm{O}$ in the sampling cell of the FMA can be assessed.

\subsection{Dilution and cross-sensitivity experiment}

Linearity and precision of the FMA and FGGA were tested in the laboratory. The instruments were connected to a common air source. Eleven concentration levels at regular intervals between 0 and $4 \mathrm{ppm}$ for $\mathrm{CH}_{4}$ and 16 between 0 and $1500 \mathrm{ppm}$ for

$5 \mathrm{CO}_{2}$ were produced by diluting $\mathrm{CH}_{4}$ and $\mathrm{CO}_{2}$ with $\mathrm{CH}_{4}$ and $\mathrm{CO}_{2}$ free air, respectively. The concentration was kept constant for $20 \mathrm{~min}$ in case of $\mathrm{CH}_{4}$ and $15 \mathrm{~min}$ for $\mathrm{CO}_{2}$. After verifying the linearity of the measurements, the precision of the $\mathrm{CH}_{4}$ measurements was checked against two National Oceanic \& Atmospheric Administration (NOAA) standards (CA04580 and CA05316). $\mathrm{H}_{2} \mathrm{O}$ was calibrated against a LI-610 10 dew point generator (Li-Cor, Lincoln, NB, USA). Further, dry air with a known $\mathrm{CH}_{4}$ and $\mathrm{CO}_{2}$ concentration was humidified to check for dilution effects and cross-sensitivity of $\mathrm{CH}_{4}$ and $\mathrm{CO}_{2}$ measurements to $\mathrm{H}_{2} \mathrm{O} . \mathrm{H}_{2} \mathrm{O}$ concentrations were set to 9 different levels between 0 and $25000 \mathrm{ppm}$ and kept constant for $20 \mathrm{~min}$. The air temperature in the laboratory was controlled during all experiments.

\section{$15 \quad 3.3$ Flux measurements}

\subsubsection{Site}

The flux measurements presented in this study were acquired at the ETH agricultural research station Chamau $\left(8^{\circ} 24^{\prime} 38^{\prime \prime} \mathrm{E}, 47^{\circ} 12^{\prime} 37^{\prime \prime} \mathrm{N}, 400\right.$ m a.s.l., Switzerland) in summer 2009. The station is located in the broad prealpine Reuss Valley. Two flux towers, a

20 mobile and a long-term one, were situated on a temperate, intensively managed grassland with mixed ryegrass-clover vegetation raised for forage (Zeeman et al., 2010).

\subsubsection{Instruments and setup}

The mobile tower consisted of a Fast Greenhouse Gas Analyzer (FGGA, Los Gatos Research, Inc., Mountain View, CA, USA) measuring concentrations of $\mathrm{CO}_{2}, \mathrm{CH}_{4}$, and $25 \mathrm{H}_{2} \mathrm{O}$ and a Solent R2A ultrasonic anemometer (Gill Instruments Ltd., Lymington, UK), 
thereafter abbreviated as sonic. The sonic was installed at a height of $1.7 \mathrm{~m}$ with the inlet for the FGGA attached to the sonic boom $25 \mathrm{~cm}$ below the instrument head. The sample was drawn through a $6.7 \mathrm{~m}$ long tube with $8 \mathrm{~mm}$ inner diameter (Synflex-1300, Eaton Performance Plastics, Cleveland, OH, USA) followed by two serially mounted 5 particle filters with integrated droplet separator (SMC, Japan, model AF30-F03 with $5 \mu \mathrm{m}$ filter and model AFM30-F03 with $0.3 \mu \mathrm{m}$ filter, respectively). The FGGA was connected to an external dry vacuum scroll pump (BOC Edwards XDS-35i, Crawly, UK) drawing 30.5 slpm to ensure turbulent flow in the sampling tube. An embedded computer (Advantech ARK-3381, Taipei, Taiwan) running a Linux system recorded the

10 raw data at $20.8 \mathrm{~Hz}$. Eugster and Plüss (2010) and Tuzson et al. (2010) provide a more detailed description of the system.

The long-term tower measured $\mathrm{CO}_{2}$ and $\mathrm{H}_{2} \mathrm{O}$ fluxes by an open-path Infrared Gas Analyzer (IRGA, Li-7500, Li-Cor, Lincoln, NB, USA) and a Solent R3 ultra sonic anemometer (Gill Instruments Ltd., Lymington, UK) at $2.40 \mathrm{~m}$ above ground, about

$155 \mathrm{~m}$ separated from the mobile tower. A more detailed description of this system can be found in Zeeman et al. (2010).

Additionally, several meteorological variables were measured: air temperature and relative humidity of the air (HygroClip S3, Rotronic AG, Bassersdorf, Switzerland), and atmospheric pressure (LI-7500, Li-Cor, Lincoln, NB, USA).

20 Even though measured by the HygroClip, relative humidity values used in the evaluations were derived from the $\mathrm{LI}-7500$ measurements $\left(\mathrm{RH}_{\mathrm{IRGA}}\right)$ due to higher accuracy of this instrument, whereas the HygroClip data were used for cross-checking the results.

\subsubsection{Flux processing}

The statistical software R (Version 2.12.1, R Development Core Team, 2010) was used 25 for all analyses. This includes the processing of the flux data from the mobile system with the R package Reddy (under development and available from the authors upon request). $\mathrm{CO}_{2}$ and $\mathrm{H}_{2} \mathrm{O}$ fluxes of the long-term tower were calculated by the in-house

software eth-flux (Mauder et al., 2008) which is also available from the authors. In eth-flux and Reddy, a two-way rotation of the wind vector was performed for each 30min interval (McMillen, 1988). The time lag between the vertical wind speed $w$ and the scalar was determined for each 30-min block such that the correlation maximized. If not

5 stated differently, this time lag was applied before calculating the respective flux. Fluxes were calculated as the covariance between the two time series following the rules of Reynold's averaging $\left(\overline{W^{\prime} c^{\prime}}\right)$ (Baldocchi, 2003). The $\mathrm{CH}_{4}$ fluxes at our site were often very small and close to the detection limit of the system. Thus the time lag between $w$ and the $\mathrm{CH}_{4}$ concentration measurements was difficult to detect since no clear peak 0 in the cross-correlation function was found. For periods with a detectable $\mathrm{CH}_{4}$ time lag, it was very similar to the one of $\mathrm{CO}_{2}$. Thus, we used the time lag found for $\mathrm{CO}_{2}$ to calculate the $\mathrm{CH}_{4}$ fluxes. The $\mathrm{H}_{2} \mathrm{O}$ flux measured by the FGGA was calculated in two ways: (1) the time lag maximizing the correlation between $w$ and the $\mathrm{H}_{2} \mathrm{O}$ signal $\left(\overline{w^{\prime} \mathrm{H}_{2} \mathrm{O}^{\prime}}{ }_{F G G A}\right)$ and (2) with the time lag found for $\mathrm{CO}_{2}\left(\overline{w^{\prime} \mathrm{H}_{2} \mathrm{O}^{\prime}}{ }_{F G G A} \operatorname{lag}\left(\overline{w^{\prime} \mathrm{CO}_{2}^{\prime}}\right)\right.$. Prior to 15 the flux calculations, all scalars of the FGGA were post-calibrated as described below.

Flux data were filtered according the following criteria. For the mobile system, fluxes were rejected if the cell pressure dropped below 100 Torr or the number of available trace gas measurements was below 20000 of 36000 within the 30-min averaging window. Further, flux records were removed if Reddy automatically detected the maximal 20 or minimal time lag within the lag detection window, namely 10 and 40 records for $\overline{w^{\prime} \mathrm{CH}_{4}^{\prime}}, 15$ and 40 records for $\overline{w^{\prime} \mathrm{H}_{2} \mathrm{O}^{\prime}}$, and 10 and 30 records for $\overline{w^{\prime} \mathrm{CO}_{2}^{\prime}}$. For the longterm station, fluxes were dismissed if the automated gain control (AGC) value by the LI-7500, the so called window dirtiness, exceeded $70 \%$ or was not a value dividable by 6.25 . Both criteria are indicators for rain or dew disturbing the measurement path.

25 Since the LI-7500 reports the AGC as a four-bit variable, 16 different values between 0 and 100 can be reported which results in incremental steps of 6.25 . Thirty-minute averages between these steps indicate temporal changes of the AGC value within the averaging period, e.g. introduced by slight rain or an insect passing the sensor path during a short part of the averaging interval. Further, fluxes were rejected when the 
friction velocity dropped below $0.08 \mathrm{~m} \mathrm{~s}^{-1}$ as suggested by Zeeman et al. (2010) for this site.

\subsubsection{Cospectra and damping loss correction}

Before the calculation of the cospectra, a two way rotation was applied to the wind 5 vectors (McMillen, 1988) and a time lag was implemented to maximize the correlation of the two time series. The scalar concentrations were converted to dry mole fractions and a correction for additional cross-sensitivity to $\mathrm{H}_{2} \mathrm{O}$ effects (see Sect. 4.1) was applied. Since no cospectral analysis function exists for $\mathrm{R}$, we wrote a new function downloadable from http://www.swissfluxnet.ch/R/. The procedure follows the suggestion by

10 Stull (1988, p.310ff) and was double-checked against the algorithm for Fast Fourier Transformation suggested by Press (1988). Thereafter, a bandwidth averaging was performed on the output (Kaimal and Gaynor, 1983) and the high frequency flux losses were quantified following Eugster and Senn (1995). A slight modification of the theoretical cospectral model introduced by Kaimal et al. (1972) is damped according to the 15 inductance $L\left[\mathrm{~s}^{-1}\right]$ in an alternating-current circuit to match the calculated cospectra. This corresponds to the standard first-order damping known from similar approaches, e.g. by Horst (1997). For unstable conditions, the cospectral approximation reads (Eq. 29 in Eugster and Senn, 1995):

$\frac{f C o_{w, c_{L}}(f)}{\overline{W^{\prime} C_{L=0}^{\prime}}}=\left\{\begin{array}{ll}10.53 n /\left[\left(1+4 \pi^{2} f^{2} L^{2}\right)(1+13.3 n)^{1.72}\right], & n \leqslant 1.0 \\ 4.21 n /\left[\left(1+4 \pi^{2} f^{2} L^{2}\right)(1+3.8 n)^{2.4}\right], & n \geqslant 1.0\end{array}\right\},-2 \leqslant \zeta \leqslant 0$,

20 and for stable conditions (Eq. 30 in Eugster and Senn, 1995):

$\frac{f C o_{w, c_{L}}(f)}{\overline{W^{\prime} C_{L=0}^{\prime}}}=\frac{1}{1+4 \pi^{2} f^{2} L^{2}} \times \frac{0.81\left(n / n_{0}\right)}{1+1.5\left(n / n_{0}\right)^{2.1}}, 0<\zeta \leqslant 2$

with

$n_{0}=\left\{\begin{array}{lr}0.23, & -2 \leqslant \zeta \leqslant 0 \\ 0.23(1+6.4 \zeta)^{3 / 4}, & 0<\zeta \leqslant 2\end{array}\right\}$.

Here, $\zeta[-]$ denotes the Monin-Obukhov stability parameter and $n$ the normalized frequency $n=f z / \bar{u}$ with $f[\mathrm{~Hz}]$ the natural frequency, $z[\mathrm{~m}]$ the measuring height above 5 zero-plane displacement, and $\bar{u}\left[\mathrm{~m} \mathrm{~s}^{-1}\right]$ the mean horizontal wind-speed along the mean wind direction.

Cospectra were calculated from 1-h blocks of high frequency data for the whole measurement period. The damping factors $L$ were retrieved by a non-linear least squares fit (function $\mathrm{nls}($ ) in $R$ ) to the individually calculated cospectra. For further analyses, $L$ was only used for periods when a detectable time lag was found within the predefined window and the fit of the idealized damped cospectrum on the calculated cospectrum was significant at $p<0.1$. $L$ was originally set constant over periods without system maintenance where the measured tracer was $\mathrm{NO}_{2}$ (Eugster and Senn, 1995). Especially for the water vapor flux, additional dampening of the signal is however observed 15 depending on the relative humidity of the air (Ibrom et al., 2007a; Mammarella et al., 2009). Therefore, $L$ was adjusted according to the following empirical model with relative humidity $\mathrm{RH}$ as predictor:

$L=a+b \times \mathrm{RH}+c \times \mathrm{RH}^{2}$,

where $a, b$, and $c$ were obtained by conditional linear regression fitting. To reduce

20 the scatter in the data, the automatically determined $L$ values were binned into relative humidity classes of $5 \%$ width. The model was fitted through the medians of each class. In constrast to $L$ for the $\mathrm{H}_{2} \mathrm{O}$ fluxes, analyses of the empirically determined $L$ for the $\mathrm{CH}_{4}$ and $\mathrm{CO}_{2}$ fluxes resulted in a constant value. The measured fluxes were corrected with the derived $L$ for damping losses following the method by Eugster and 25 Senn (1995). 


\section{Results}

\subsection{Dilution and cross-sensitivity experiment}

The linearity of the instruments was tested in a dilution experiment (data not shown). Comparing the median of the measurements at each level against the given concentra5 tions, $R^{2}$ yields 0.999997 for the FMA and 0.999995 for the FGGA. This implies that a two-point calibration is sufficient to calibrate the instrument. $\mathrm{CH}_{4}$ was calibrated against two NOAA standards (1.713 ppm and $1.905 \mathrm{ppm}$ ). The linear relationship through these two points (in ppm) yielded:

$$
\begin{aligned}
& \mathrm{CH}_{4}=-0.0147+1.0002 \times \mathrm{CH}_{4, \mathrm{FMA}} \\
& \mathrm{CH}_{4}=-0.0024+0.9774 \times \mathrm{CH}_{4, \mathrm{FGGA}} .
\end{aligned}
$$

10 The calibration of the FGGA $\mathrm{H}_{2} \mathrm{O}$ signal determined the following polynomial of the second order (in ppm):

$$
\begin{aligned}
& \mathrm{H}_{2} \mathrm{O}_{\text {ref }}=\left(\begin{array}{lll}
-52.36 & \pm 8.01
\end{array}\right) \\
&\left(\begin{array}{ll}
1.011 & \pm 0.002
\end{array}\right) \times \mathrm{H}_{2} \mathrm{O}_{\mathrm{FGGA}}+ \\
&(0.00000239 \pm 0.00000007) \times \mathrm{H}_{2} \mathrm{O}_{\mathrm{FGGA}}^{2}
\end{aligned}
$$

where $\mathrm{H}_{2} \mathrm{O}_{F G G A}$ refers to the $\mathrm{H}_{2} \mathrm{O}$ humid mole fraction measured with the FGGA and $\mathrm{H}_{2} \mathrm{O}_{\text {ref }}$ to the dry mole fraction of the dew point generator, both measured in or con-

15 verted to $\mathrm{ppm}$. The uncertainty in the parameter estimate is given with \pm one standard error and the $R^{2}$ yields 0.999 . The FGGA overestimates $\mathrm{H}_{2} \mathrm{O}$ concentrations at low concentrations up to $\approx 5000 \mathrm{ppm}$ and thereafter overestimates them. For the following analysis, the water vapor signal was post-calibrated according to the parameter fit in Eq. (9).

20 The dilution experiment described in Sect. 3.2 showed a drop of the $\mathrm{CO}_{2}$ and $\mathrm{CH}_{4}$ humid mole fractions that was triggered by the changes of humidity. Most of the drop can be explained by the dilution of the air by water vapor (difference of the black and dark grey points in Fig. 1). The dark grey points correspond to the dry mole fraction 363

reported by the FGGA. However, a small part of the drop, the difference between dark and light grey points in Fig. 1, was not caused by dilution and hence must result from different processes. Rella (2010) suggested the following equation to calculate the dry mole fraction for the Picarro G1301 analyzer, here adapted for the FGGA instrument:

$5 c=c_{\mathrm{FGGA}} /\left(1+a \times \mathrm{H}_{2} \mathrm{O}+b \times \mathrm{H}_{2} \mathrm{O}^{2}\right)$,

where $\mathrm{H}_{2} \mathrm{O}$ is the corrected $\mathrm{H}_{2} \mathrm{O}$ dry mole fraction measured by the FGGA and $c_{\mathrm{FGGA}}$ the measured humid mole fraction of the issued dry mole fraction $c$ of $\mathrm{CO}_{2}$ or $\mathrm{CH}_{4}$. Table 1 shows the empirical coefficients for Eq. (10) which combines the dilution effect as well as other water dependent processes influencing the measured concentration.

The additional water dependent processes affect the measured concentration in a similar way as the dilution effect. To correct the effect of density fluctuations caused by the dilution, the WPL correction (Eq. 2) can be applied. The dilution is a linear process while Eq. (10) additionally includes the square of $\mathrm{H}_{2} \mathrm{O}$. The derivation of the WPL correction would be severely complicated if the square term is included. Since

15 the performance of a simple linear model, same as Eq. (10) but without term $b \times \mathrm{H}_{2} \mathrm{O}^{2}$, is similar (compare corresponding $R^{2}$ in Tables 1 and 2), we decided to use the latter for the further analysis. The details for the individual gases and instruments can be found in Table 2.

An additional fit of Eq. (10) was determined for $\mathrm{CH}_{4}$ measured by the FMA with $\mathrm{H}_{2} \mathrm{O}$ 20 taken from the measurements of the FGGA. The results only marginally differs from Fig. 1b (not shown). The results for the fit can be found in Table 1 and 2.

\subsection{Damping loss correction}

The automatically fitted damping factor $L$ for $\overline{w^{\prime} \mathrm{H}_{2} \mathrm{O}^{\prime}}$ FGGA, lag( $\overline{\left.w^{\prime} \mathrm{CO}_{2}^{\prime}\right)}$ shows a clear dependency on the relative humidity (see Fig. 2). Such dependency of $L$ on the relative 25 humidity would also be found if the $L$ for $\overline{w^{\prime} \mathrm{H}_{2} \mathrm{O}^{\prime}}$ at the time lag maximizing $\overline{w^{\prime} \mathrm{H}_{2} \mathrm{O}^{\prime}}$ were used (not shown). The increase in $L$ with increasing relative humidity can by 
explained by sorption and desorption effects. The variability of the $\overline{w^{\prime} \mathrm{H}_{2} \mathrm{O}^{\prime}}$ parallel increases with increasing $L$. This can be explained by lower water vapor fluxes at high relative humidity and hence a less well defined cospectrum. The automatic fits of $L$ are less robust and result in a higher scattering. Since outliers would strongly influence the

5 parameter fit for the relationship between $L$ and the relative humidity, $L$ was binned into relative humidity classes of $5 \%$ width. A polynomial of the 2 nd order was fitted through the medians of the individual classes, which yields:

$L \frac{w^{\prime} \mathrm{H}_{2} \mathrm{O}^{\prime}}{\mathrm{FGGA}_{\text {lag }\left(\mathrm{w}^{\prime} \mathrm{CO}_{2}^{\prime}\right)}}=1.07-2.99 \times 10^{-2} \times \mathrm{RH}_{\mathrm{IRGA}}+3.62 \times 10^{-4} \times \mathrm{RH}_{\mathrm{IRGA}}^{2}$,

with $\mathrm{RH}_{\mathrm{IRGA}}$ [\%] being the relative humidity obtained from the air temperature measured by the HygroClip and the $\mathrm{H}_{2} \mathrm{O}$ concentration measured by the LI-7500 IRGA. This relationship between $L$ and the relative humidity was used in the flux processing to determine the damping factor for the water vapor flux and correct the flux therewith for damping losses. No dependency on relative humidity was found for the $\mathrm{CO}_{2}$ and $\mathrm{CH}_{4}$ fluxes (not shown). For these two trace gases, $L$ seems to be a constant as proposed in the original paper by Eugster and Senn (1995).

\subsection{Signal desynchronisation}

Different time lags to maximize the covariance $\overline{w^{\prime} \mathrm{H}_{2} \mathrm{O}^{\prime}}$ and $\overline{w^{\prime} \mathrm{CO}_{2}^{\prime}}$ were found. Based on the assumption that no time lag would be observed under ambient conditions, we guess that the signal of $\mathrm{CO}_{2}$ and $\mathrm{H}_{2} \mathrm{O}$ was desynchronized on the way from the inlet

20 to the measurement cell. Figure 3 shows the histogram of the determined time lags between $w$ and the particular scalar concentration. In general, the peak of $\overline{w^{\prime} \mathrm{H}_{2} \mathrm{O}^{\prime}}$ moved towards longer lags compared to $\overline{w^{\prime} \mathrm{CO}_{2}^{\prime}}$. Also the distribution of $\overline{w^{\prime} \mathrm{H}_{2} \mathrm{O}^{\prime}}$ lags was wider than the one for $\overline{w^{\prime} \mathrm{CO}_{2}^{\prime}}$. For $\overline{w^{\prime} \mathrm{CH}_{4}^{\prime}}$, the distribution of time lags was almost uniform because the flux at our site was very low. However, the comparison of the time lag distribution of $\overline{w^{\prime} \mathrm{CH}_{4}^{\prime}}$ in the two panels in Fig. 3 reveals that there is a slight 365

difference seen in the range where the $\overline{w^{\prime} \mathrm{H}_{2} \mathrm{O}^{\prime}}$ time lag was most frequent (20-30 records). For $\mathrm{CH}_{4}$ humid mole fractions, more cases with a lag in this range were observed than for dry mole fractions. Since the $\mathrm{CH}_{4}$ flux was very low at our site, the water-introduced fluctuations in the $\mathrm{CH}_{4}$ signal were sometimes stronger than the 5 natural variations of $\mathrm{CH}_{4}$, which resulted in lags for $\mathrm{CH}_{4}$ being identical to those of $\overline{w^{\prime} \mathrm{H}_{2} \mathrm{O}^{\prime}}$.

For $\overline{w^{\prime} \mathrm{H}_{2} \mathrm{O}^{\prime}}$, the time lag clearly depended on the relative humidity (Fig. 4a) while it stayed constant for $\overline{w^{\prime} \mathrm{CO}_{2}^{\prime}}$. This explains the wider distribution of the peak for time lags of $\overline{w^{\prime} \mathrm{H}_{2} \mathrm{O}^{\prime}}$ compared to $\overline{w^{\prime} \mathrm{CO}_{2}^{\prime}}$ in Fig. 3. Nevertheless, more records lacked a 10 detectable time lag during conditions of high relative humidity for $\overline{W^{\prime} \mathrm{CO}_{2}^{\prime}}$, and lags of $\overline{w^{\prime} \mathrm{H}_{2} \mathrm{O}^{\prime}}$ were hardly detectable at $\mathrm{RH}_{\mathrm{IRGA}}>95 \%$.

The ratio between $\overline{w^{\prime} \mathrm{H}_{2} \mathrm{O}^{\prime}}$ FGGA, lag( $\overline{\left(w^{\prime} \mathrm{CO}_{2}^{\prime}\right)}$ and $\overline{w^{\prime} \mathrm{H}_{2} \mathrm{O}^{\prime}}{ }_{\mathrm{FGGA}}$ decreased with increasing relative humidity as a result of higher temporal separation of the optimal lags of $\mathrm{CO}_{2}$ and $\mathrm{H}_{2} \mathrm{O}$ (see Fig. 4b). The median observed $\overline{w^{\prime} \mathrm{H}_{2} \mathrm{O}^{\prime}}$ flux losses were increasing up

15 to $30 \%$ at highest relative humidity. However, $\overline{w^{\prime} \mathrm{H}_{2} \mathrm{O}^{\prime}}$ was smaller in these conditions than during dryer periods, and thus the absolute flux difference was minimal. Looking at the cospectra of $\overline{w^{\prime} \mathrm{H}_{2} \mathrm{O}^{\prime}}$, the flux difference appears visible as an additional damping of the signal (see Fig. 5). This observation agrees well with the relative humidity dependent damping losses found for $\overline{w^{\prime} \mathrm{H}_{2} \mathrm{O}^{\prime}}$ (Eq. 11).

The $\mathrm{H}_{2} \mathrm{O}$ concentration measurements of the FGGA tend to be lower than those measured by the LI-7500 IRGA. This ratio between $\mathrm{H}_{2} \mathrm{O}_{\text {FGGA }}$ and $\mathrm{H}_{2} \mathrm{O}_{\text {IRGA }}$ decreased with increasing relative humidity (see Fig. 6). For the comparison, the $\mathrm{H}_{2} \mathrm{O}$ measurements from the FGGA were converted from dry mole fractions to $\mathrm{mmol} \mathrm{m}^{-3}$, the unit recorded by the IRGA. Points were ecluded from the analysis if the $\mathrm{H}_{2} \mathrm{O}$ concentration 25 measured by the two instruments diverted by more than $20 \%$ (7 out of 933 points). A non-linear model fits the medians of the $5 \%$ relative humidity bin very well. The 
relationship yields:

$\frac{\mathrm{H}_{2} \mathrm{O}_{\mathrm{FGGA}}}{\mathrm{H}_{2} \mathrm{O}_{\mathrm{IRGA}}}=1.072-2.528 \times 10^{-3} \times \mathrm{RH}_{\mathrm{IRGA}}+1.146 \times 10^{-5} \times \mathrm{RH}_{\mathrm{IRGA}}^{2}$

\subsection{Flux comparison}

Putting the previous findings together, the $\overline{w^{\prime} \mathrm{H}_{2} \mathrm{O}^{\prime}}$ FGGA,lag( $\overline{\left.w^{\prime} \mathrm{CO}_{2}^{\prime}\right)}$ should be scal5 able to match the atmospheric $\overline{W^{\prime} \mathrm{H}_{2} \mathrm{O}^{\prime}}{ }_{\mathrm{IRGA}}$, e.g. measured by the LI-7500. Therefore, $\overline{w^{\prime} \mathrm{H}_{2} \mathrm{O}^{\prime}}$ FGGA, lag $\left(\overline{w^{\prime} \mathrm{CO}_{2}^{\prime}}\right)$ was post-calibrated according to Eq. (9) and the damping loss correction applied with the damping factor calculated from the relative humidity

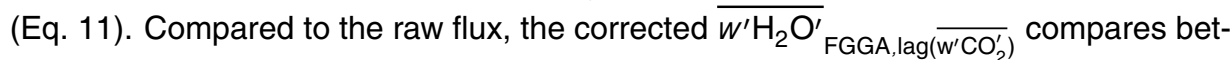
ter with the $\overline{w^{\prime} \mathrm{H}_{2} \mathrm{O}^{\prime}}$ IRGA. In addition to the post-calibration of the water concentration 0 and the application of the damping correction, the flux was also corrected for the observed signal reduction with increasing relative humidity (Eq. 12). The combination of all corrections reduced the difference between $\overline{w^{\prime} \mathrm{H}_{2} \mathrm{O}^{\prime}}{ }_{\mathrm{FGGA}, \operatorname{lag}\left(\overline{w^{\prime} \mathrm{CO}_{2}^{\prime}}\right)}$ and $\overline{w^{\prime} \mathrm{H}_{2} \mathrm{O}^{\prime}{ }_{\mathrm{IRGA}}}$ considerably, where the latter contributed $5 \%$ to the total improvement of $47 \%$ (see Fig. 7).

\section{4.5 Adapted WPL correction}

The information about the damping of $\overline{w^{\prime} \mathrm{H}_{2} \mathrm{O}^{\prime}}$ by the instrumental setup and the crosssensitivity of other trace gas measurements to $\mathrm{H}_{2} \mathrm{O}$ provides the basis for the adapted WPL correction. This modified correction can be applied to fluxes measured by the FMA where $\mathrm{H}_{2} \mathrm{O}$ is not measured. The heat term of the original WPL correction (see

20 Eq. 2) is negligible for the FMA since it is a closed-path instrument (Leuning, 2005). The adapted WPL correction yields:

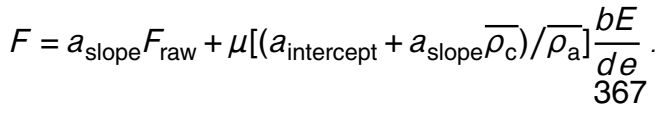

The factors $a_{\text {slope }}$ and $a_{\text {intercept }}$ apply the post-calibration of the concentration measurements as described in Sect. 4.1, Eq. (8). Since means are removed when calculating fluxes, the intercept can be omitted for the flux, but must be included in the postcalibration of the density of the trace gas.

5 The additional water dependent cross-sensitivities affect the measurements in a similar way as the dilution effect and can be expressed as an amplification of the dilution effect. The linear correction approach (Eq. 10 without term $b \times \mathrm{H}_{2} \mathrm{O}^{2}$, see Table 2) implies that, in case of $\mathrm{CH}_{4}$, the dilution effect is amplified by $18 \%$. Therefore, the water vapor flux $E$ must be multiplied with 1.18, denoted as factor $b$ in Eq. (13).

10 Since $\overline{w^{\prime} \mathrm{H}_{2} \mathrm{O}^{\prime}}$ observed in the measurement cell controls the density flux effects caused by $\mathrm{H}_{2} \mathrm{O}$, the atmospheric $\overline{w^{\prime} \mathrm{H}_{2} \mathrm{O}^{\prime}}$ needs to be modified such that it fits the observed flux in the cell. Therefore, the corrections derived for $\overline{w^{\prime} \mathrm{H}_{2} \mathrm{O}^{\prime}}$ FGGA, lag $\left.\overline{\left(\mathrm{w}^{\prime} \mathrm{CO}_{2}^{\prime}\right.}\right)$ were reverted and applied to the atmospheric $\overline{w^{\prime} \mathrm{H}_{2} \mathrm{O}^{\prime}}$ to reconstruct the conditions in the cell. The damping factor $L$ was calculated according to Eq. (11) and the damping

15 effect assessed according to Eqs. (4) or (5), depending on the stability of the atmosphere. $E$ in Eq. (13) was divided by the calculated damping effect $d$ (Eq. 11) and by $e$ that accounts for the reduced $\mathrm{H}_{2} \mathrm{O}$ concentration in the sampling cell (Eq. 12) to simulate $\overline{w^{\prime} \mathrm{H}_{2} \mathrm{O}^{\prime}}$ FGGA, lag $\overline{\left(w^{\prime} \mathrm{CO}_{2}^{\prime}\right.}$.

The damping of the water vapor flux reduces the correction by about $20 \%$ compared 20 to the original correction (see Fig. 8). However, this reduction is compensated by the spectral broadening effect due to $\mathrm{H}_{2} \mathrm{O}$. The final result compares well with the flux calculated from dry mole fractions. In total, the clear $\mathrm{CH}_{4}$ uptake is reduced to a near zero flux after applying all corrections.

\section{Discussion}

25 The manufacturer's calibration of the FGGA and FMA agreed very well with the measurements against $\mathrm{CH}_{4}$ calibration standards as also noted by Detto et al. (2011). 
They found very small instrumental drifts for their FMA and FGGA and suggest that no post-calibration is needed for eddy covariance applications. However, $\mathrm{CH}_{4}$ and $\mathrm{CO}_{2}$ measurements depend on $\mathrm{H}_{2} \mathrm{O}$. Additional to the dilution effect, a cross-sensitivity on $\mathrm{H}_{2} \mathrm{O}$ was found. This occurrence was already observed for a FMA (Tuzson et al.,

5 2010) and other laser spectrometers of various brands (Chen et al., 2010; Tuzson et al., 2010; Neftel et al., 2010; McDermitt et al., 2010). Such an interference is no problem as long as $\mathrm{H}_{2} \mathrm{O}$ is measured simultaneously in the same measurement cell as the other trace gas. The effect can be quantified in a dilution experiment as described in Sect. 3.2. Picarro Inc. and Licor Inc. published the factors for their instruments

10 Picarro G1301 and Licor Li-7700 (Rella, 2010; McDermitt et al., 2010). Meanwhile, new instruments by Los Gatos Research Inc. already correct for cross-sensitivity effects (FMA with serial numbers starting from 11-0049 and above and FGGA starting from 11-0018) and hence no additional correction is needed. FMA and FGGA with serial numbers 10-0150 and below do not include water correction, but the instrument 15 can be upgraded by the manufacturer. Instruments with serial numbers inbetween might correct or are user upgradable and Los Gatos Research Inc. will provide instrument specific information upon request (Robert Provencal, personal communication, 13 September 2011). Instruments that do not measure $\mathrm{H}_{2} \mathrm{O}$ perform best if additional measurements of $\overline{w^{\prime} \mathrm{H}_{2} \mathrm{O}^{\prime}}$ are available to correct for dilution and cross-sensitivity ef20 fects of $\mathrm{H}_{2} \mathrm{O}$. The needed dilution factors can be derived from a dilution experiment added to the traditional WPL correction. Another option would be to dry the air sample before the analysis which might however introduce negative effects to the frequency response and high-frequency performance of the sensor (Griffis et al., 2008).

Further, the conditions in the sampling cell are decisive for the WPL correction. The 25 water vapor flux is damped by the measurement system and hence is reduced in the cell. Therefore, atmospheric water vapor flux would overcorrect the dilution effect. The damping strength of the system depends on the tubing, filters, etc. and is therefore different for individual setups. Additionally, environmental variables such as wind speed and atmospheric stability influence the damping strength (see Sect. 3.3.4). For water

vapor, the damping also depends on relative humidity (Mammarella et al., 2009; Ibrom et al., 2007a,b). Smeets et al. (2009) already adapted the WPL correction following the suggestions by Ibrom et al. (2007b) for this issue. They used a FMA that does not measure $\mathrm{H}_{2} \mathrm{O}$ and thus had no possibility to validate their assumption. Moreover, they 5 did not address the additional cross-sensitivity effects of $\mathrm{CH}_{4}$ humid mole fractions on $\mathrm{H}_{2} \mathrm{O}$. Detto et al. (2011) stated that they found no difference between the flux calculated from dry mole fractions and the flux corrected with the water vapor flux derived from an external sensor (LI-7500) for their FGGA. This agrees with our findings. Nevertheless, the original WPL term accounting for the dilution of the air sample by $\mathrm{H}_{2} \mathrm{O}$ is reduced.

10 This reduction is however compensated by the cross-sensitivity of the measurements to $\mathrm{H}_{2} \mathrm{O}$.

The dependency of the damping on relative humidity can be at least partially attributed to the likeliness that the tube walls and filters on the way to the cell absorb and desorb water molecules. For $\mathrm{CO}_{2}$ and $\mathrm{CH}_{4}$, no dependency was found and the 15 system seems to be inert to these gases. Compared to other trace gases, the sorption processes of water prolong the travelling time of $\mathrm{H}_{2} \mathrm{O}$ into the sampling cell. The different time lag introduces a phase shift between $\mathrm{H}_{2} \mathrm{O}$ and e.g. $\mathrm{CO}_{2}$ which leads to an additional damping of $\overline{w^{\prime} \mathrm{H}_{2} \mathrm{O}^{\prime}}$ FGGA, lag( $\overline{\left(\mathrm{w}^{\prime} \mathrm{CO}_{2}^{\prime}\right)}$ at the time lag of $\overline{w^{\prime} \mathrm{CO}_{2}^{\prime}}$.

We additionally observed a reduction of measured water vapor concentration with 20 increasing relative humidity. The used particle filters are designed to retain liquid water, e.g. if the instrument is operated under foggy conditions. Unfortunately, we found that the filter material itself is not hydrophobic enough and thus introduces a memory effect in the $\mathrm{H}_{2} \mathrm{O}$ signal. If the humidity of the atmosphere increases, the filter retains some water, even though the air is not saturated. Reversely, water in the filter reevaporates if 25 the air dries. This might be a reason for the observed reduction in $\mathrm{H}_{2} \mathrm{O}$ concentrations measured by the FGGA. 


\section{Conclusions}

Our results show that the damping of the water vapor signal as well as cross-sensitivity effects to water affect the measured trace gas flux. While the damping reduces $\overline{w^{\prime} \mathrm{H}_{2} \mathrm{O}^{\prime}}$ observed in the cell, the cross-sensitivity effects counteract the damping. For our setup,

5 the two processes coincidentally compensated each other. Hence, the original WPL correction would lead to the same result as our adapted approach which accounts for the individual processes that affect the water vapor flux. However, the damping of $\overline{w^{\prime} \mathrm{H}_{2} \mathrm{O}^{\prime}}$ is system specific and depends on deployed filters etc. Therefore, our approach is not generally valid, but provides at least an estimate for the order of magni-

10 tude of the described effects.

Acknowledgements. This project was funded by the Competence Center Environment an Sustainability at the ETH Domain (CCES). We thank Hans-Ruedi Wettstein, manager of the agricultural research station Chamau for access to the field site and Sebastian Wolf for his valuable comments on the manuscript.

\section{References}

Baer, D., Paul, J., Gupta, M., and O'Keefe, A.: Sensitive absorption measurements in the near-infrared region using off-axis integrated-cavity-output spectroscopy, Appl. Phys. B, 75, 261-265, 2002. 353

Baldocchi, D. D.: Assessing the eddy covariance technique for evaluating carbon dioxide exchange rates of ecosystems: past, present and future, Glob. Change Biol., 9, 479-492, 2003. 352,360

Chen, H., Winderlich, J., Gerbig, C., Hoefer, A., Rella, C. W., Crosson, E. R., Van Pelt, A. D., Steinbach, J., Kolle, O., Beck, V., Daube, B. C., Gottlieb, E. W., Chow, V. Y., Santoni, G. W., and Wofsy, S. C.: High-accuracy continuous airborne measurements of greenhouse gases

$25 \quad\left(\mathrm{CO}_{2}\right.$ and $\left.\mathrm{CH}_{4}\right)$ using the cavity ring-down spectroscopy (CRDS) technique, Atmos. Meas. Tech., 3, 375-386, doi:10.5194/amt-3-375-2010, 2010. 369

Crosson, E.: A cavity ring-down analyzer for measuring atmospheric levels of methane, carbon dioxide, and water vapor, Appl. Phys. B, 92, 403-408, 2008. 353

Detto, M., Verfaillie, J., Anderson, F., Xu, L., and Baldocchi, D.: Comparing laser-based open- and closed-path gas analyzers to measure methane fluxes using the eddy covariance method, Agr. Forest Meteorol., 151, 1312-1324, doi:10.1016/j.agrformet.2011.05.014, 2011. 356, 368, 370

Eugster, W. and Plüss, P.: A fault-tolerant eddy covariance system for measuring $\mathrm{CH}_{4}$ fluxes, Agr. Forest Meteorol., 150, 841-851, doi:10.1016/j.agrformet.2009.12.008, 2010. 353, 359

Eugster, W. and Senn, W.: A cospectral correction model for measurement of turbulent $\mathrm{NO}_{2}$ flux, Bound.-Lay. Meteorol., 74, 321-340, 1995. 361, 362, 365

Eugster, W., Zeyer, K., Zeeman, M., Michna, P., Zingg, A., Buchmann, N., and Emmenegger, L.: Methodical study of nitrous oxide eddy covariance measurements using quantum cascade laser spectrometery over a Swiss forest, Biogeosciences, 4, 927-939, doi:10.5194/bg-4927-2007, 2007. 353

15 Griffis, T. J., Sargent, S. D., Baker, J. M., Lee, X., Tanner, B. D., Greene, J., Swiatek, E., and Billmark, K.: Direct measurement of biosphere-atmosphere isotopic $\mathrm{CO}_{2}$ exchange using the eddy covariance techniques, J. Geophys. Res., 113, D08304, doi:10.1029/2007JD009297, 2008. 353, 369

Hendriks, D. M. D., Dolman, A. J., van der Molen, M. K., and van Huissteden, J.: A compact and stable eddy covariance set-up for methane measurements using off-axis integrated cavity output spectroscopy, Atmos. Chem. Phys., 8, 431-443, doi:10.5194/acp-8-431-2008, 2008. 353

Horst, T. W.: A simple formula for attenuation of eddy fluxes measured with first-order-response scalar sensors, Bound.-Lay. Meteorol., 82, 219-233, 1997. 361

25 Ibrom, A., Dellwik, E., Flyvbjerg, H., Jensen, N. O., and Pilegaard, K.: Strong low-pass filtering effects on water vapour flux measurements with closed-path eddy correlation systems, Agr. Forest Meteorol., 147, 140-156, 2007a. 354, 357, 362, 370

Ibrom, A., Dellwik, E., Larsen, S. E., and Pilegaard, K.: On the use of the Webb-PearmanLeuning theory for closed-path eddy correlation measurements, Tellus B, 59, 937-946, 2007b. 355, 357, 370

Kaimal, J. C. and Gaynor, J.: The Boulder Atmospheric Observatory, J. Climate Appl. Meteor., 22, 863-880, 1983. 361

Kaimal, J. C., Wyngaard, J. C., Izumi, Y., and Coté, O. R.: Spectral characteristics of surface- 
layer turbulence, Quart. J. Roy. Meteorol. Soc., 98, 563-589, doi:10.1002/qj.49709841707, 1972. 361

Kroon, P. S., Hensen, A., Jonker, H. J. J., Zahniser, M. S., van 't Veen, W. H., and Vermeulen, A. T.: Suitability of quantum cascade laser spectroscopy for $\mathrm{CH}_{4}$ and $\mathrm{N}_{2} \mathrm{O}$ eddy covariance

5 flux measurements, Biogeosciences, 4, 715-728, doi:10.5194/bg-4-715-2007, 2007. 353

Leuning, R.: Measurements of trace gas fluxes in the atmosphere using eddy covariance: WPL corrections revisited, in: Handbook of Micrometeorology, edited by: Lee, X., Massman, W., and Law, B., Vol. 29 of Atmospheric and Oceanographic Sciences Library, 119-132, Springer Netherlands, doi:10.1007/1-4020-2265-4_6, 2005. 367

10 Leuning, R. and Judd, M. J.: The relative merits of open- and closed-path analysers for measurement of eddy fluxes, Glob. Change Biol., 2, 241-253, doi:10.1111/j.13652486.1996.tb00076.x, 1996. 356

Mammarella, I., Launiainen, S., Gronholm, T., Keronen, P., Pumpanen, J., Rannik, Ü., and Vesala, T.: Relative humidity effect on the high-frequency attenuation of water vapor flux

15 measured by a closed-path eddy covariance system, J. Atmos. Ocean. Technol., 26, 18561866, doi:10.1175/2009JTECHA1179.1, 2009. 357, 362, 370

Massman, W.: Concerning the measurement of atmospheric trace gas fluxes with open- and closed-path eddy covariance system: The WPL terms and spectral attenuation, in: Handbook of Micrometeorology, edited by: Lee, X., Massman, W., and Law, B., 29 of Atmospheric

20 and Oceanographic Sciences Library, 133-160, Springer, The Netherlands, doi:10.1007/14020-2265-4_7, 2005. 357

Massman, W. and Clement, R.: Uncertainty in eddy covariance flux estimates resulting from spectral attenuation, in: Handbook of Micrometeorology, edited by Lee, X., Massman, W., and Law, B., 29 of Atmospheric and Oceanographic Sciences Library, 67-99, Springer, The Netherlands, doi:10.1007/1-4020-2265-4_4, 2005. 357

Mauder, M., Foken, T., Clement, R., Elbers, J. A., Eugster, W., Grünwald, T., Heusinkveld, B., and Kolle, O.: Quality control of CarboEurope flux data - Part 2: Inter-comparison of eddy-covariance software, Biogeosciences, 5, 451-462, doi:10.5194/bg-5-451-2008, 2008. 360

30 McDermitt, D., Burba, G., Xu, L., Anderson, T., Komissarov, A., Riensche, B., Schedlbauer, J., Starr, G., Zona, D., Oechel, W., Oberbauer, S., and Hastings, S.: A new low-power, openpath instrument for measuring methane flux by eddy covariance, Appl. Phys. B, 1-15-15, 2010. 353,369

McMillen, R. T.: An eddy correlation technique with extended applicability to non-simple terrain, Bound.-Lay. Meteorol., 43, 231-245, 1988. 360, 361

Neftel, A., Ammann, C., Fischer, C., Spirig, C., Conen, F., Emmenegger, L., Tuzson, B., and Wahlen, S.: $\mathrm{N}_{2} \mathrm{O}$ exchange over managed grassland: Application of a quantum cascade

5 laser spectrometer for micrometeorological flux measurements, Agr. Forest Meteorol., 150, 775-785, 2010. 353, 369

Press, W. H.: Numerical recipes in C, Cambridge University Press, 1988. 361

R Development Core Team: R: A language and environment for statistical computing, R Foundation for Statistical Computing, Vienna, Austria, available at: http://www.R-project.org/, ISBN 3-900051-07-0, 2010. 359

Rella, C.: Accurate greenhouse gas measurements in humid gas streams using the Picarro G1301 carbon dioxide/methane/water vapor gas analyzer, Picarro, Inc., Sunnyvale, California, 2010. 353, 364, 369

Smeets, C. J. P. P., Holzinger, R., Vigano, I., Goldstein, A. H., and Röckmann, T.: Eddy covariance methane measurements at a Ponderosa pine plantation in California, Atmos. Chem. Phys., 9, 8365-8375, doi:10.5194/acp-9-8365-2009, 2009. 353, 357, 370

Stull, R.: An introduction to boundary layer meteorology, Kluwer Academic Pub, 1988. 361

Tuzson, B., Hiller, R. V., Zeyer, K., Eugster, W., Neftel, A., Ammann, C., and Emmenegger, L.: Field intercomparison of two optical analyzers for $\mathrm{CH}_{4}$ eddy covariance flux measurements, Atmos. Meas. Tech., 3, 1519-1531, doi:10.5194/amt-3-1519-2010, 2010. 353, 359, 369

Webb, E., Pearman, G., and Leuning, R.: Correction of flux measurements for density effects due to heat and water vapour transfer, Quart. J. Roy. Meteorol. Soc., 106, 85-100, 1980. 354,355

Zeeman, M. J., Hiller, R., Gilgen, A. K., Michna, P., Plüss, P., Buchmann, N., and Eugster, W.:

25 Management and climate impacts on net $\mathrm{CO}_{2}$ fluxes and carbon budgets of three grasslands along an elevational gradient in Switzerland, Agr. Forest Meteorol., 150, 519-530, doi:10.1016/j.agrformet.2010.01.011, 2010. 358, 359, 361 
Table 1. Fitted parameters for Eq. (10) $\left(\mathrm{CO}_{2}, \mathrm{CH}_{4}\right.$, and $\mathrm{H}_{2} \mathrm{O}$ in ppm).

\begin{tabular}{ccccc}
\hline Parameter & Unit & Values for $\mathrm{CO}_{2, \mathrm{FGGA}}$ & Values for $\mathrm{CH}_{4, \mathrm{FGGA}}$ & Values for $\mathrm{CH}_{4, \mathrm{FMA}}$ \\
\hline $\mathrm{a}$ & {$\left[\mathrm{ppm}^{-1}\right]$} & $\begin{array}{c}-1.219 \times 10^{-06} \\
\left( \pm 2.169 \times 10^{-09}\right)\end{array}$ & $\begin{array}{c}-1.189 \times 10^{-06} \\
\left( \pm 1.480 \times 10^{-09}\right)\end{array}$ & $\begin{array}{c}-1.219 \times 10^{-06} \\
\left( \pm 1.182 \times 10^{-09}\right)\end{array}$ \\
& & $\begin{array}{c}1.229 \times 10^{-12} \\
\left( \pm 1.073 \times 10^{-13}\right)\end{array}$ & $\begin{array}{c}2.096 \times 10^{-13} \\
\left( \pm 7.318 \times 10^{-14}\right)\end{array}$ & $\begin{array}{c}1.678 \times 10^{-12} \\
\left( \pm 5.846 \times 10^{-14}\right)\end{array}$ \\
$\mathrm{b}$ & {$\left[\mathrm{ppm}^{-2}\right]$} & 0.9928 & 0.9966 & 0.9992 \\
$R^{2}$ & & 0 &
\end{tabular}

Table 2. Fitted parameters for Eq. (10) without term $b \times \mathrm{H}_{2} \mathrm{O}^{2}\left(\mathrm{CO}_{2}, \mathrm{CH}_{4}\right.$, and $\mathrm{H}_{2} \mathrm{O}$ in ppm).

\begin{tabular}{ccccc}
\hline Parameter & Unit & Values for $\mathrm{CO}_{2, \mathrm{FGGA}}$ & Values for $\mathrm{CH}_{4, \mathrm{FGGA}}$ & Values for $\mathrm{CH}_{4, \mathrm{FMA}}$ \\
\hline $\mathrm{a}$ & {$\left[\mathrm{ppm}^{-1}\right]$} & $-1.195 \times 10^{-06}$ & $-1.184 \times 10^{-06}$ & $-1.186 \times 10^{-06}$ \\
$R^{2}$ & & $\left( \pm 5.825 \times 10^{-10}\right)$ & $\left( \pm 3.952 \times 10^{-10}\right)$ & $\left( \pm 3.265 \times 10^{-10}\right)$ \\
& & 0.9927 & 0.9966 & 0.9991 \\
\hline
\end{tabular}



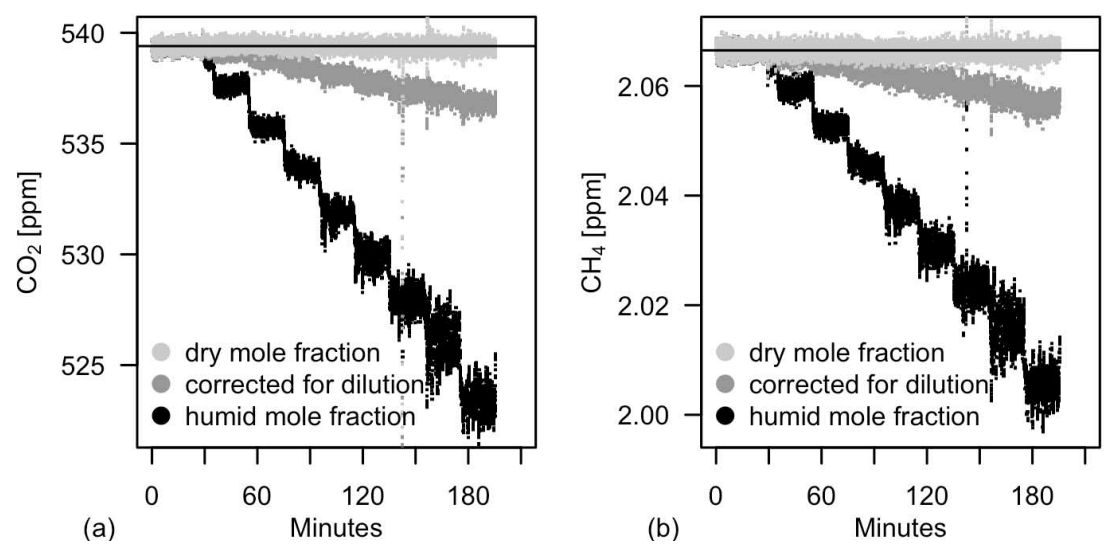

Fig. 1. Results from the dilution experiment for $\mathrm{CO}_{2}$ (a) and $\mathrm{CH}_{4}$ (b). Moisture was added to the dry gas at 9 increasing levels, which were held constant over $20 \mathrm{~min}$. The dilution of the gas explains most of concentration drop (difference between black and dark grey points). However, a small portion cannot be attributed to this process (difference between dark and light grey points) and must have a different source, which is also related to the water vapor concentration. The solid line indicates the mixing ratio of the supplied air.

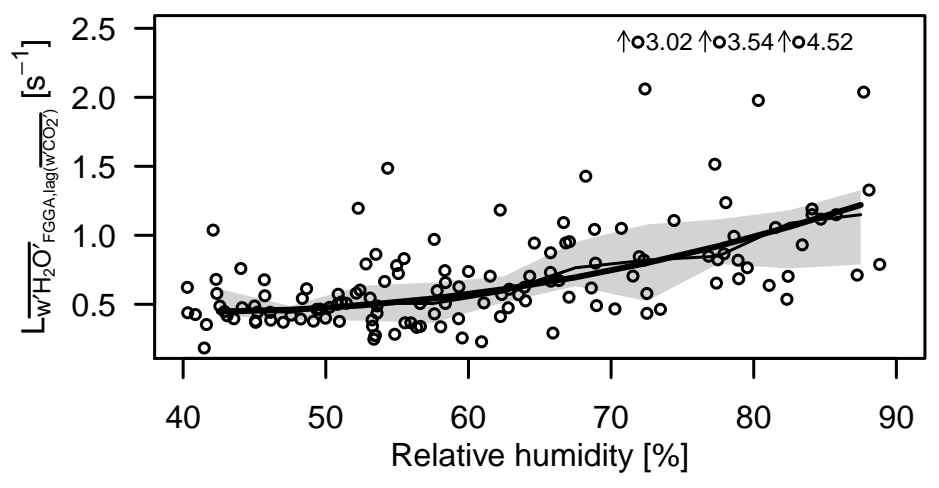

Fig. 2. Damping factor $L$ for $\overline{W^{\prime} \mathrm{H}_{2} \mathrm{O}^{\prime}}$ FGGA lag $\overline{\left.\mathrm{w}^{\prime} \mathrm{CO}_{2}^{\prime}\right)}$ related to relative humidity. The grey band shows the interquartile range for $5 \%$ relative humidity bins with at least 8 observations. This corresponds to $50 \%$ of all observed values. The fine line connects the medians of the individual bins and the bold line indicates the model fit through the medians. 

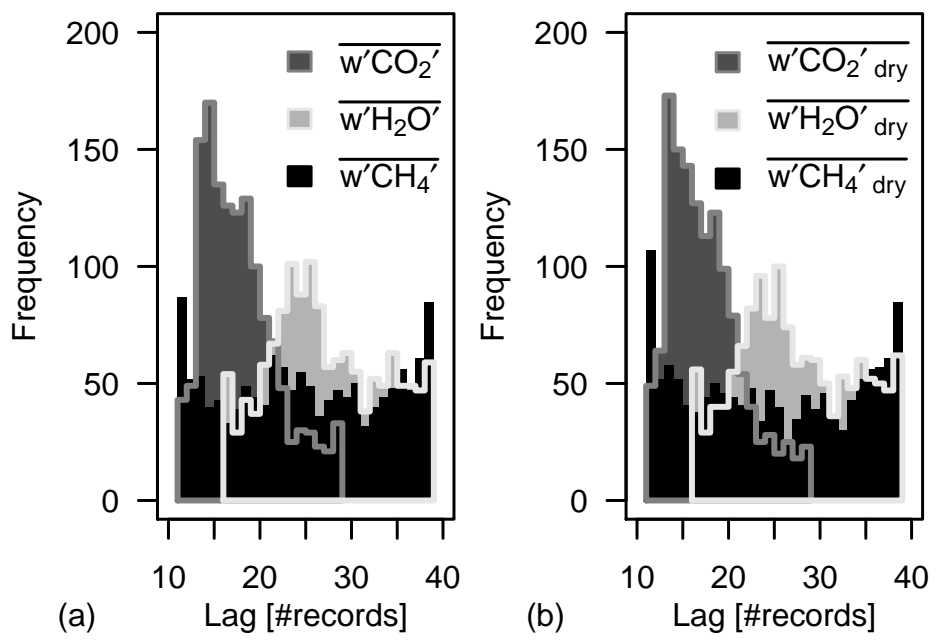

Fig. 3. Histograms of the time lags for $\overline{w^{\prime} \mathrm{CO}_{2}^{\prime}}, \overline{w^{\prime} \mathrm{H}_{2} \mathrm{O}^{\prime}}$, and $\overline{w^{\prime} \mathrm{CH}_{4}^{\prime}}$ within the search window of 10-40 records (0.5-2 s). In (a), the time lags were determined from humid mole fractions whereas in (b), dry mole fractions were used. Only records where all three fluxes showed a detectable time lag were selected and thus the number of observations is equal for all gases of the individual histogram.

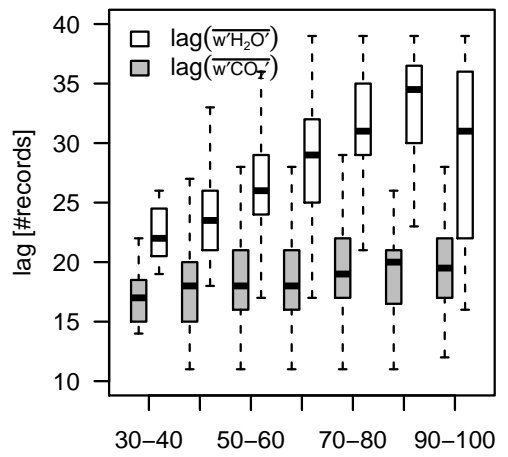

(a)

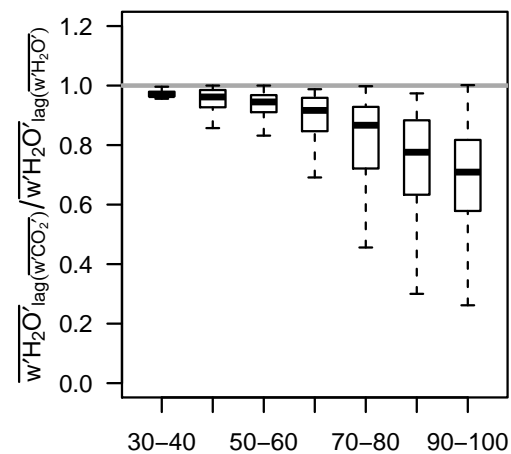

(b)

Fig. 4. (a): time lags of $\overline{w^{\prime} \mathrm{H}_{2} \mathrm{O}^{\prime}}$ depend on the relative humidity of the air whereas no such relation was found for $\overline{w^{\prime} \mathrm{CO}_{2}^{\prime}}$. (b): the relative difference between the water vapor flux at the time lag of $\overline{w^{\prime} \mathrm{CO}_{2}^{\prime}}$ and at the optimal lag maximizing $\overline{w^{\prime} \mathrm{H}_{2} \mathrm{O}^{\prime}}$. 


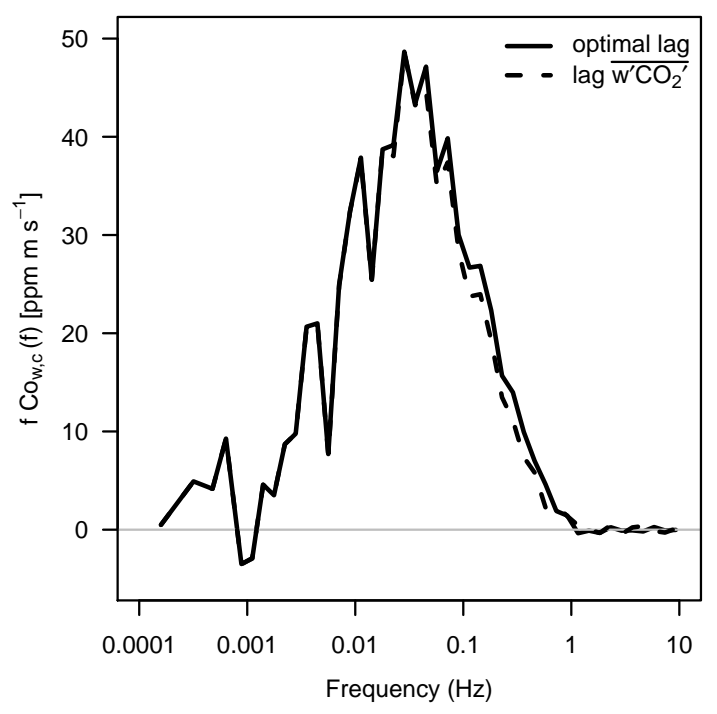

Fig. 5. Cospectrum of $\overline{w^{\prime} \mathrm{H}_{2} \mathrm{O}^{\prime}}$ for 26 July 2009 11:40-13:25 CET (2 ${ }^{17}$ records). The solid line shows the cospectrum of $w$ and $\mathrm{H}_{2} \mathrm{O}$ at the time lag maximizing the flux. The dashed line represents the cospectrum of $\overline{w^{\prime} \mathrm{H}_{2} \mathrm{O}^{\prime}}$ at the time lag of $\overline{w^{\prime} \mathrm{CO}_{2}^{\prime}}$. The total flux is slightly lower with considerable damping in the higher frequencies. The relative humidity of the air was around $54 \%\left(\approx 640 \mathrm{mmol} \mathrm{m}^{-3}\right)$.

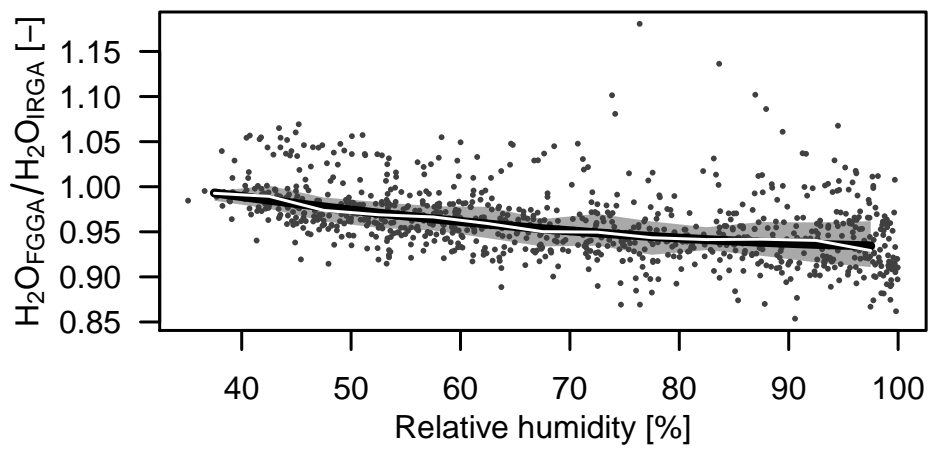

Fig. 6. Water vapor concentration ratio between the FGGA and LI-7500 decreases with higher relative humidity of the air. The dots show the individual data points. The band represents the interquartile range for $5 \%$ relative humidity bins. The black line indicates the polynomial fit of the second order through the class medians whereas the white line connects the medians of the classes. 


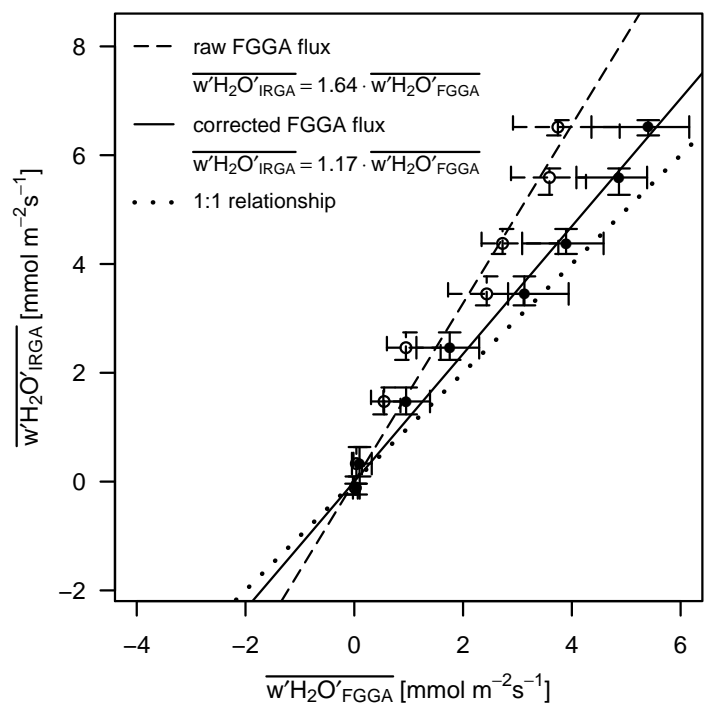

Fig. 7. Water vapor fluxes of the two systems. $\overline{w^{\prime} \mathrm{H}_{2} \mathrm{O}^{\prime}}{ }_{\mathrm{IRGA}}$ were binned into classes of $1 \mathrm{mmol} \mathrm{m}{ }^{-2} \mathrm{~s}^{-1}$. The symbols denote the median values for both variables within the class. The cross hairs span the interquartile range. The dashed line represents the values before

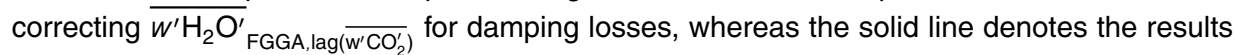
thereafter. The dotted line indicates the $1: 1$ relationship.

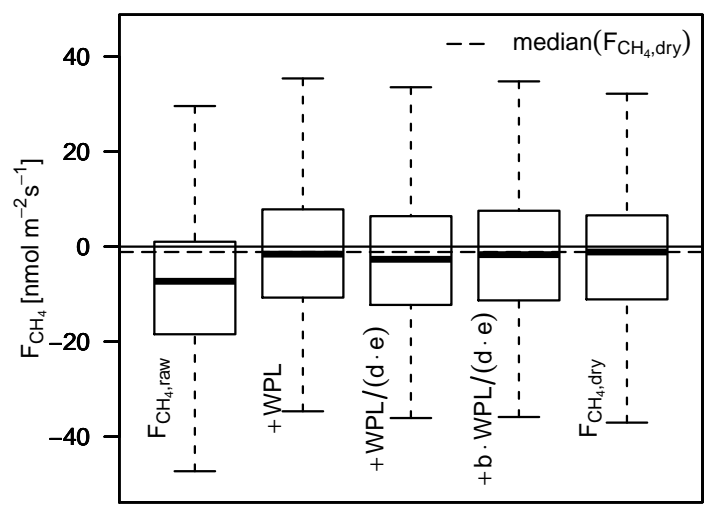

Fig. 8. Boxplots of the observed raw and corrected $\mathrm{CH}_{4}$ fluxes. From left to right, the first one shows the raw flux. The second boxplot shows the flux after applying the original WPL term. In the third one, the water vapor flux is damped as it would be observed in the instrument whereas the forth also includes the spectral broadening effect of the instrument. The last boxplot is considered the reference flux: the flux when raw values are converted to dry mole fractions before the calculation of the covariance. The solid line is drawn at zero and the dashed line indicates the expected value, the median of the reference flux. 